\title{
Effect and interaction between wheat bran and zinc oxide on productive performance and intestinal health in post-weaning piglets
}

\author{
Francesc Molist*, Rafael Gustavo Hermes, Arantza Gómez de Segura, Susana María Martín-Orúe, \\ Josep Gasa, Edgar Garcia Manzanilla and José Francisco Pérez \\ Grup de Recerca en Nutrició, Maneig i Benestar Animal, Departament de Ciència Animal i dels Aliments, Facultat de \\ Veterinària, Universitat Autònoma de Barcelona, 08193 Bellaterra, Spain
}

(Received 7 April 2010 - Revised 23 July 2010 - Accepted 16 September 2010 - First published online 11 April 2011)

\begin{abstract}
The inclusion of fibre has been studied as an alternative to antimicrobials in weaning pig diets, while $\mathrm{ZnO}$ is used as an effective method to prevent post-weaning diarrhoea. However, it has not been investigated to what extent these two strategies interact with each other. The present study was designed to evaluate the effects of including wheat bran (WB) and $\mathrm{ZnO}$ alone or combined in the diet of early-weaning pigs on productive performance and microbial activity in the gastrointestinal tract (trial 1). A total of sixty-four piglets were distributed in a $2 \times 2$ factorial combination of two levels of WB $(0 v .40 \mathrm{~g} / \mathrm{kg})$ and $\mathrm{ZnO}(0 v .3 \mathrm{~g} / \mathrm{kg})$ in the diet. The inclusion of ZnO in the diet improved the feed intake and growth of the animals and reduced the incidence of diarrhoea. The inclusion of WB increased SCFA concentrations and decreased Escherichia coli counts. However, simultaneous incorporation of WB and ZnO increased E. coli counts. Two in vitro trials were also designed to clarify hypotheses derived from the in vivo test: (1) the ability of WB and other fibre sources to bind $E$. coli in vitro (trial 2 ) and (2) the in vitro interactions between WB and $\mathrm{ZnO}$ with respect to E. coli growth (trial 3). We can conclude that incorporation of WB in the diet improved gut health by modulating the activity and composition of the microbial population. The negative interaction between WB and $\mathrm{ZnO}$ raises the interest of considering the inclusion of phytase enzymes to reduce the therapeutic levels of $\mathrm{ZnO}$ in post-weaning diets.
\end{abstract}

Key words: Colibacillosis: Microbiota: Piglets: Post-weaning diets

Post-weaning colibacillosis is a diarrhoeal disease of young pigs, strongly influenced by the drastic changes faced by the piglets immediately after weaning. Reduced feed intake, intestinal villous atrophy and reduced enzymatic and absorptive capacity of the gut may result in impaired digestion and absorption of nutrients and in the overgrowth of bacteria such as enterotoxigenic Escherichia coli ${ }^{(1)}$. The main aetiological agents are those enterotoxigenic E. coli expressing fimbrial antigens, which mediate adhesion to complementary carbohydrates located in the brush borders of villous enterocytes $^{(2,3)}$

So far, the most common strategy used to prevent enterotoxigenic $E$. coli growth in the intestine has been the addition of in-feed antimicrobial agents ${ }^{(4)}$. In those situations when the use of sub-therapeutic doses of antimicrobial agents has been suppressed (i.e. in the European Union in $2006^{(5)}$ ), the prescription of therapeutic antimicrobial agents has considerably increased $^{(6)}$. In some European Union countries, pharmacological doses of $\mathrm{ZnO}$ (2500-3000 parts per million) are now extensively used in feed during the first 2 weeks after weaning to reduce the incidence of post-weaning E. coli diarrhoea ${ }^{(7)}$. Besides having antimicrobial properties, some authors have proposed that high doses of $\mathrm{Zn}$ may increase feed intake by promoting an increase in the synthesis of ghrelin in the digestive $\operatorname{tract}^{(8)}$ and may also reduce the inflammation of the intestinal mucosa ${ }^{(9)}$. Although the use of pharmacological doses of $\mathrm{ZnO}$ does not have the downside of selecting microbial resistances with its subsequent implications in human medicine (as opposed to the use of antibiotics), its use has raised environmental concerns about the low retention of $\mathrm{Zn}$ by pigs and soil toxicity.

Considerably, efforts are being made in the search of an efficient replacer of antimicrobial agents. One of the possible alternatives would be to modify the main ingredients of the feed formula to promote fermentation in the hindgut, which would protect animals from opportunistic bacterial proliferation. Several reports support that low-crude protein $\operatorname{diets}^{(10,11)}$, diets including protein of animal origin ${ }^{(7)}$ or diets supplemented with fermentable carbohydrates (such as high lactose levels ${ }^{(12)}$ or wheat bran (WB) and sugarbeet

Abbreviations: CT, control diet; OD, optical density; PA, phytic acid; TRF, terminal restriction fragments; WB, wheat bran.

*Corresponding author: F. Molist, fax +34 935811494, email francesc.molist@gmail.com 
pulp $^{(13,14)}$ ) may also help to maintain enteric health by lowering protein fermentation and promoting the proliferation of commensal microbiota ${ }^{(15)}$. In previous studies, inclusion of WB in the diet of early-weaned pigs increased intestinal fermentation $^{(16,17)}$ and diminished the incidence of diarrhoea and the attachment of $E$. coli K88 to the ileum mucosa ${ }^{(18)}$. The beneficial effects of fibrous ingredients could also be explained by additional mechanisms. Recent studies have shown, in vitro ${ }^{(19)}$ and in vivo ${ }^{(20)}$, that dietary fibres from plants, because of their carbohydrate nature and low digestibility, may act as receptor analogues, which block the attachment of bacteria to the intestinal tract. However, no information is available regarding the ability of WB to block the attachment of $E$. coli to the intestinal tract.

Therefore, nutritionists have two main strategies available: either using an antimicrobial approach, which tends to delay microbiota maturation to later stages, or designing diets to promote and modulate the establishment of commensal microbiota in the intestinal tract immediately after weaning. This second option, however, requires a better knowledge of the effects of dietary components on digestive physiology and on the dynamic of the microbiota ecosystem. Both these strategies appear to be contradictory in the mode of action and are difficult to combine in a comprehensive way. However, in practice, they are frequently used together, although there is little information on the formulation of starter diets containing medicines. It would be of particular interest to know about the possible influence of dietary composition on the activity of pharmacological doses of $\mathrm{ZnO}$ in the diet.

In the present study, we evaluate the productive performance and gut microbiota responses associated with the incorporation of $\mathrm{ZnO}$, WB or their combination in the diet of early-weaned piglets (trial 1). Two in vitro trials were also designed to clarify hypotheses derived from the in vivo test: (1) the ability of WB and other fibre sources to bind E. coli in vitro (trial 2) and (2) the in vitro interactions between WB and $\mathrm{ZnO}$ with respect to E. coli growth (trial 3).

\section{Materials and methods}

\section{Trial 1: in vivo experiment}

Animals and diets. This experiment was performed at the Animal Facilities of the Universitat Autònoma de Barcelona and received prior approval from the Animal Protocol Review Committee of this institution. The treatment, management, housing, husbandry and slaughtering conditions conformed to the European Union Guidelines ${ }^{(21)}$. A total of sixty-four commercial crossbred piglets ((Large White $\times$ Landrace) $\times$ Pietrain), which had been excluded from receiving creep feed, were weaned at $21 \mathrm{~d}$ of age with an average body weight of 6.7 (SEM 0.37$) \mathrm{kg}$. Pigs were transported from a commercial farm to the University facilities and were allocated into thirty-two pens (two animals/pen) based on the litter origin and body weight. Pens were allotted to four dietary treatments (eight replicates/treatment; Table 1) in a $2 \times 2$ factorial arrangement that included two levels of WB ( $0 v$. $40 \mathrm{~g} / \mathrm{kg}$, control diet (CT) $v$. WB, respectively) and two levels of $\mathrm{ZnO}(0 v .3 \mathrm{~g} / \mathrm{kg}$, CT $v$. ZnO diet, respectively) in the diet. The diets were formulated to be isoenergetic (averaging $16 \cdot 1 \mathrm{MJ} / \mathrm{kg}$ ) and isoproteic (averaging $182 \mathrm{~g}$ crude protein $/ \mathrm{kg}$ ) based on ground maize, barley and soyabean protein concentrate.

Experimental procedures and sampling. Animals received the diets from day 1 to 12 of the experiment. Individual body weight and pen feed consumption were recorded on days 0, 3, 6, 9 and 12 after weaning. Physical and behavioural examination of the animals was done daily to evaluate their health status. Samples of fresh faeces were collected from the rectum of one animal/pen for microbial counts on days 3, 6, 9 and 12 after weaning. At the end of the experimental period, the faecal samples were kept in tubes and immediately frozen at $-80^{\circ} \mathrm{C}$ for analysing the microbial structure, quantifying the lactobacilli counts and determining the SCFA concentration.

Analytical procedures. Chemical analyses of the diets (Table 1) were performed according to the Association of Official Analytical Chemists ${ }^{(22)}$ standard procedures.

Traditional culture methods were used to determine some bacterial groups. The faecal samples were diluted 1:10 in PBS (Sigma, St Louis, MO, USA) immediately after collection, and subsequently homogenised. Viable counts of enterococci

Table 1. Composition and chemical analysis of pre-starter diets*

\begin{tabular}{|c|c|c|c|c|}
\hline & \multicolumn{4}{|c|}{ Diets } \\
\hline & CT & WB & $\mathrm{ZnO}$ & $\mathrm{WB}-\mathrm{ZnO}$ \\
\hline \multicolumn{5}{|l|}{ Ingredients (g/kg DM) } \\
\hline Maize & $414 \cdot 0$ & $367 \cdot 0$ & $414 \cdot 0$ & $364 \cdot 0$ \\
\hline Barley & $200 \cdot 0$ & $200 \cdot 0$ & $200 \cdot 0$ & $200 \cdot 0$ \\
\hline Whey & $112 \cdot 0$ & $102 \cdot 0$ & $112 \cdot 0$ & $102 \cdot 0$ \\
\hline High-fat whey & $69 \cdot 0$ & $90 \cdot 0$ & $69 \cdot 0$ & $90 \cdot 0$ \\
\hline Soyabean protein concentrate & $55 \cdot 0$ & $52 \cdot 0$ & $55 \cdot 0$ & $52 \cdot 0$ \\
\hline Spray-dried porcine plasma & $50 \cdot 0$ & $50 \cdot 0$ & $50 \cdot 0$ & $50 \cdot 0$ \\
\hline Wheat gluten & $30 \cdot 0$ & $30 \cdot 0$ & $30 \cdot 0$ & $30 \cdot 0$ \\
\hline Fishmeal LT† & $40 \cdot 0$ & $40 \cdot 0$ & $40 \cdot 0$ & $40 \cdot 0$ \\
\hline Wheat bran & - & $40 \cdot 0$ & - & $40 \cdot 0$ \\
\hline $\mathrm{CaCO}_{3}$ & $10 \cdot 0$ & $10 \cdot 0$ & $10 \cdot 0$ & $10 \cdot 0$ \\
\hline Dicalcium phosphate & $7 \cdot 0$ & $7 \cdot 0$ & $7 \cdot 0$ & $7 \cdot 0$ \\
\hline Benzoic acid & $5 \cdot 0$ & $5 \cdot 0$ & $5 \cdot 0$ & $5 \cdot 0$ \\
\hline Synthetic amino acids $\ddagger$ & $11 \cdot 2$ & $11 \cdot 2$ & $11 \cdot 2$ & $11 \cdot 2$ \\
\hline Vitamin and mineral premix§ & $3 \cdot 7$ & $3 \cdot 7$ & $3 \cdot 7$ & $3 \cdot 7$ \\
\hline $\mathrm{ZnO}$ & - & - & $3 \cdot 0$ & $3 \cdot 0$ \\
\hline \multicolumn{5}{|l|}{ Chemical analysis (g/kg DM) } \\
\hline $\mathrm{DM}$ & $902 \cdot 0$ & $903 \cdot 0$ & $902 \cdot 0$ & $903 \cdot 0$ \\
\hline Gross energy (MJ/kg) & $17 \cdot 8$ & $17 \cdot 9$ & $17 \cdot 8$ & $17 \cdot 9$ \\
\hline Crude protein $(\mathrm{N} \times 6.25)$ & $203 \cdot 0$ & $200 \cdot 0$ & $203 \cdot 0$ & $200 \cdot 0$ \\
\hline Neutral-detergent fibre & $79 \cdot 0$ & $92 \cdot 0$ & $79 \cdot 0$ & $92 \cdot 0$ \\
\hline Acid-detergent fibre & $23 \cdot 0$ & $28 \cdot 0$ & $23 \cdot 0$ & $28 \cdot 0$ \\
\hline Diethyl ether extract & $63 \cdot 0$ & $79 \cdot 0$ & $63 \cdot 0$ & $79 \cdot 0$ \\
\hline Ash & $56 \cdot 0$ & $57 \cdot 0$ & $56 \cdot 0$ & 57.0 \\
\hline
\end{tabular}

CT, control diet; WB, wheat bran diet.

*Trial 1: in vivo experiment.

†Fishmeal LT, fishmeal low temperature: product obtained by removing most of the water and some or all of the oil from fish by heating at low temperature $\left(<70^{\circ} \mathrm{C}\right)$ and by pressing.

$¥$ Synthetic amino acids: L-Lys 0.99, DL-Met 0.99, L-Try 0.10, L-Thr 0.98.

§Supplied per kg of feed: $13000 \mathrm{IU}(3900 \mu \mathrm{g})$ vitamin A, $1800 \mathrm{IU}(45 \mu \mathrm{g})$ vitamin $\mathrm{D}_{3}, 60.0 \mathrm{mg}$ vitamin $\mathrm{E}, 3.0 \mathrm{mg}$ vitamin $\mathrm{K}_{3}, 2.0 \mathrm{mg}$ vitamin $\mathrm{B}_{1}, 6.0 \mathrm{mg}$ vitamin $\mathrm{B}_{2}$, $3.0 \mathrm{mg}$ vitamin $B_{6}, 0.02 \mathrm{mg}$ vitamin $B_{12}, 35.0 \mathrm{mg}$ niacin, $15.0 \mathrm{mg}$ calcium pantothenate, $0.12 \mathrm{mg}$ biotin, $1 \mathrm{mg}$ folic acid, $20.0 \mathrm{mg} \mathrm{Fe}, 120.0 \mathrm{mg} \mathrm{Cu}, 110 \mathrm{mg} \mathrm{Zn}$, $45.0 \mathrm{mg} \mathrm{Mn}, 0.30 \mathrm{mg} \mathrm{Se}, 0.10 \mathrm{mg} \mathrm{Co}, 1 \mathrm{mg} \mathrm{I}$ and $2.5 \mathrm{mg}$ ethoxyquin as an antioxidant (Capsoquin; Itpsa, Barcelona, Spain). 
were done by plating serial tenfold dilutions onto Chromocult $^{\mathrm{TM}}$ Enterococci-Agar (Merck K GaA, Darmstadt, Germany) and incubating the plates for $24 \mathrm{~h}$ at $37^{\circ} \mathrm{C}$. For the enumeration of E. coli and coliforms, $1 \mathrm{ml}$ of solution of the corresponding dilution was pipetted onto an E. coli-coliform count plate (3M Petrifilm; Europe Laboratories 3M Santé, Cergy-Pontoise, France) with Violet Red Bile gel as an indicator of glucuronidase activity. The plates were incubated for $48 \mathrm{~h}$ at $35^{\circ} \mathrm{C}$, and the colonies were counted following the manufacturer's instructions. DNA from faeces was extracted and purified using the commercial QIAamp DNA Stool Mini Kit (Qiagen, West Sussex, UK), and the lactobacilli population was quantified by real-time PCR using SYBR Green dye, following Castillo et al. ${ }^{(23)}$. The terminal restriction fragment length polymorphism analysis of bacterial community was performed following the procedure described by Hojberg et $a l^{(24)}$ and adapted by Castillo et $a l^{(25)}$. Finally, SCFA concentrations were determined by GC, after an acid-base treatment followed by diethyl ether extraction and derivatisation ${ }^{(26)}$.

\section{Trial 2: in vitro adhesion test}

Fibrous ingredients. Seven different fibrous ingredients, WB, rice hulls, soyabean hulls, oat hulls, pea hulls, sugarbeet pulp and cereal straw, were selected as test products. Bovine serum albumin (Sigma) served as the reference (negative control), following the protocol described by Becker et al. ${ }^{(27)}$.

Bacterial strains. Two different $E$. coli strains were used in this experiment to elucidate the interaction between fibre substrates and bacterial fimbriae. The first one was an $E$. coli K88 (enterotoxigenic E. coli, strain FV12048) isolated from a colibacillosis outbreak in Spain ${ }^{(28)}$; the serotype $(\mathrm{O} 149: \mathrm{K} 91: \mathrm{H} 10, \mathrm{~F} 4+$, LT1 +, STb + ) was provided by the E. coli Reference Laboratory, Veterinary Faculty of Santiago de Compostela (Lugo). The other strain was a non-fimbriated E. coli $(\mathrm{F} 4-, \mathrm{F} 6-, \mathrm{F} 18-, \mathrm{LT} 1-, \mathrm{ST} 1-, \mathrm{ST} 2+$, Stx2e - ) isolated from the faeces of post-weaning piglets and kindly donated by the Departament de Sanitat i Anatomia Animal from the Universitat Autònoma de Barcelona.

Bacteria were cultured in unshaken Luria broth (Sigma) at $37^{\circ} \mathrm{C}$ and serially passaged every $48 \mathrm{~h}$, at least five times. Bacterial cells from the culture were harvested and processed as described earlier ${ }^{(27)}$.

Adhesion test methodology. E. coli K88 and the nonfimbriated strain were allowed to adhere to different fibre components supplied as well coatings in microplates in a miniaturised adhesion test, following the protocol described by Becker et al. ${ }^{(27)}$. Briefly, fibre ingredients were suspended in PBS to a final concentration of $4 \%(\mathrm{w} / \mathrm{v})$, and the soluble fraction was extracted for coating the flat-bottom wells of high-binding polystyrene microtitration plates. After blocking the non-specific sites with BSA, bacteria were added to a final concentration of $1.20 \times 10^{8}$ colony-forming units $/ \mathrm{ml}$. Bacteria were allowed to adhere by incubation at room temperature for $30 \mathrm{~min}$. Afterwards, the wells were washed to remove non-adherent bacteria, and bacteria were allowed to grow in Luria broth media by incubation in a microplate reader (SPECTRAmax 384 Plus; Molecular Devices Corporation, Sunnyvale, CA, USA) at $37^{\circ} \mathrm{C}$. Bacterial growth was monitored as optical density (OD) at $650 \mathrm{~nm}$ at intervals of $10 \mathrm{~min}$. The test principle, as described by Becker et al. ${ }^{(27)}$, is based on an inverse relationship between initial cell densities and the appearance of growth defined as the duration (h) needed for the cultures to reach an OD of 0.05 at $650 \mathrm{~nm}\left(t_{\mathrm{OD}}=0.05\right)$ : the higher the adhering cell numbers, the shorter the detection times of growth.

\section{Trial 3: in vitro wheat bran and zinc oxide interaction test}

Sample preparation. In order to elucidate the interaction between WB and $\mathrm{ZnO}$ and the likely role of phytates, eight different samples were prepared in a $4 \times 2$ factorial design, which included four different buffered solutions (a negative control; 4\% WB; 4\% WB + 0.02\% phytase enzyme $(5000 \mathrm{IU} / \mathrm{g}$; Ronozyme $^{\mathrm{TM}}$ P500; DSM Nutritional Products Limited, Basel, Switzerland); and 4\% WB $+0.02 \%$ xylanase and glucanase enzyme mixture (22000 visco units/g xylanase and 2000 visco units/g glucanase/g; Rovabio ${ }^{\mathrm{TM}}$ Excel AP, Adisseo, France), and two levels of $\mathrm{ZnO}(0 v \cdot 0 \cdot 3 \%, \mathrm{w} / \mathrm{v})$. Samples of buffered solutions were adjusted to a $\mathrm{pH}$ of $5 \cdot 1$ with $\mathrm{HCl}$ and incubated for $4 \mathrm{~h}$ at room temperature. Then, the suspensions were sonicated three times for $30 \mathrm{~s}$ each and then centrifuged at $460 \mathrm{~g}$ for $5 \mathrm{~min}$. The supernatant obtained was adjusted to a $\mathrm{pH}$ of $7 \cdot 0$ with $\mathrm{NaOH}$ and $\mathrm{ZnO}$ added appropriate to the specific treatment.

Bacterial strains. Two different E. coli strains (E. coli K88 and a non-fimbriated $E$. coli strain) were used in this experiment as described earlier.

In vitro test. E. coli $\mathrm{K} 88$ and the non-fimbriated E. coli strains were centrifuged $(1700 \mathrm{~g})$ and adjusted to a final concentration of approximately $3.5-3.9 \times 10^{8}$ colony-forming units $/ \mathrm{ml}$ in Luria broth. Subsequently, $750 \mu \mathrm{l}$ of each bacterial suspension were incubated with $750 \mu$ l of each experimental treatment. Thereafter, $300 \mu \mathrm{l}$ of each suspension were added to polystyrene microtitration plates, and the growth of the bacteria was measured in a microplate reader at $37^{\circ} \mathrm{C}$ following the protocol described by Becker et al. ${ }^{(27)}$. Bacterial growth was monitored as OD at $650 \mathrm{~nm}$ at intervals of $10 \mathrm{~min}$ for $10 \mathrm{~h}$. All readings were done in two independent assays and in triplicate per assay.

\section{Statistical analyses}

The OD data from the in vitro experiments were processed by non-linear regression analysis using the non-linear P-NLIN (Gauss-Newton method) procedure ${ }^{(29)}$ following the equations described by Becker et al. ${ }^{(27)}$ in order to obtain $t_{\mathrm{OD}}=0.05(\mathrm{~h})$ for each treatment.

The $t_{\mathrm{OD}}=0.05(\mathrm{~h})$ results from the in vitro tests (trials 2 and 3 ), as well as all data from the in vivo trial (trial 1) were subjected to ANOVA using the generalised linear model procedure $^{(29)}$. Classification factors included in each model were $\mathrm{WB}, \mathrm{ZnO}$ level and their interaction for trial 1, fibrous ingredient, bacterial strain and their interaction for trial 2 and buffered solution, $\mathrm{ZnO}$ inclusion and their interaction 
for trial 3. Means were calculated as least-squared means, and multiple mean comparisons were done using Tukey's correction. The $\alpha$ level for the determination of significance was 0.05 , and tendencies for $0.05<P<0.15$ were also presented.

\section{Results}

\section{Trial 1: in vivo experiment}

Animal performance and health status. The effects of WB and $\mathrm{ZnO}$ on the average daily feed intake and average daily gain of the animals as well as the incidence of diarrhoea are shown in Table 2. The inclusion of $\mathrm{ZnO}$ in the diet increased the average daily feed intake of the animals from day 6 to 12 $(P=0.006)$ and from day 0 to $12(P=0.035)$. This resulted in an increased average daily gain of the animals for the same periods ( $P=0.008$ and 0.036 , respectively) and a higher body weight at the end of the experiment $(P=0 \cdot 044)$ compared with the animals not receiving $\mathrm{ZnO}$ in the feed. The inclusion of $\mathrm{ZnO}$ in the diet also reduced the incidence of diarrhoea ( $P=0.009)$.

Metabolic activity and composition of faecal microbiota. Concentrations of total and individual SCFA in the faecal samples and also the counts of major bacterial groups using culturing methods or quantitative PCR are given in Table 3. Significant differences were observed for the SCFA concentration associated with the incorporation of $\mathrm{WB}$ and $\mathrm{ZnO}$ in the diet. Moreover, the interaction between $\mathrm{WB}$ and $\mathrm{ZnO}$ was also significant for the total SCFA $(P=0 \cdot 048)$, propionic acid $(P=0.018)$ and butyric acid concentrations $(P=0.007)$ and also tended to be significant $(P=0 \cdot 120)$ for acetic acid. Thus, the WB diet increased the total SCFA, propionic acid and butyric acid concentrations in comparison with the CT, $\mathrm{ZnO}$ and $\mathrm{WB}-\mathrm{ZnO}$ diets. The incorporation of $\mathrm{WB}$ (WB and WB- $\mathrm{ZnO}$ diets) increased the concentration of isoacids $(P=0 \cdot 001)$, and the inclusion of $\mathrm{ZnO}(\mathrm{ZnO}$ and $\mathrm{WB}-\mathrm{ZnO}$ diets) diminished the concentrations of acetic acid $(P=0.024)$ and isoacids $(P=0 \cdot 001)$.
A significant interaction was observed between the $\mathrm{ZnO}$ and WB supplementation on the counts of E. coli and coliform after weaning. The simultaneous incorporation of $\mathrm{ZnO}$ and WB in the diet increased the E. coli and coliform counts compared with the $\mathrm{ZnO}$ diet on day 6 after weaning $(P=0.026)$ and compared with the WB diet on day 9 after weaning $(P=0.024)$. On day 12 , animals fed the WB diet showed lower counts of $E$. coli $(P=0.034)$ and coliforms $(P=0.028)$ than those fed the CT diet, but no significant differences were observed with the $\mathrm{ZnO}$ or WB-ZnO diet. On day 12, the incorporation of $\mathrm{ZnO}$ in the diets $(\mathrm{ZnO}$ and $\mathrm{WB}-\mathrm{ZnO})$ also tended to increase the enterococci population $(P=0.064)$ and to reduce the lactobacilli counts $(P=0.084)$ in the faeces of pigs compared with that in the animals that did not receive $\mathrm{ZnO}$.

The terminal restriction fragment length polymorphism method was employed to evaluate global changes in the microbial ecosystem. Fig. 1 shows the analysis focused on two of the diets: the WB and $\mathrm{ZnO}$ diets. It shows the microbial profiles of all pens except one from which we were unable to take faecal samples. The effect of the diet on the composition of faeces was clearly observed as most of the animals were grouped into two separate clusters. Microbial profiles of pigs fed the WB diet were more similar (50-75\%) than those of pigs fed the $\mathrm{ZnO}$ diet, which showed more heterogeneous microbial profiles (52-90\%). In silico restriction, using Ribosomal Database Project II and MiCA software (version 3; Department of Biological Sciences, University of Idaho; http://mica.ibest.uidaho.edu/ $)^{(30)}$, was used to deduce potential ecological changes in the samples. Results are presented as potential compatible bacterial species. The WB dietary treatment showed higher diversity in compatible terminal restriction fragments (TRF) than the $\mathrm{ZnO}$ or the $\mathrm{WB}-\mathrm{ZnO}$ treatment exposed by the following results: four animals of the WB treatment showed a TRF of 105-106 bp that was not found in any of the other three treatments (CT, $\mathrm{ZnO}$ and WB-ZnO). Possible bacteria compatible with this fragment size are Bacteroides fragilis (102 bp), Prevotella ruminicola

Table 2. Body weight (BW; g), average daily feed intake (ADFI, g/animal per d), average daily gain (ADG, g/animal per d) and diarrhoea incidence (no. of animals) in early-weaned pigs*

(Mean values with their standard errors, $n 8$ )

\begin{tabular}{|c|c|c|c|c|c|c|c|c|c|}
\hline & \multirow[b]{2}{*}{ Period (d) } & \multicolumn{4}{|c|}{ Diets } & \multirow[b]{2}{*}{ SEM } & \multicolumn{3}{|c|}{$P$} \\
\hline & & $\mathrm{CT}$ & WB & $\mathrm{ZnO}$ & $\mathrm{WB}-\mathrm{ZnO}$ & & WB & $\mathrm{ZnO}$ & $\mathrm{WB} \times \mathrm{ZnO}$ \\
\hline \multicolumn{10}{|l|}{ Performance results } \\
\hline \multirow[t]{3}{*}{ BW } & 0 & 6700 & 6725 & 6742 & 6698 & $53 \cdot 7$ & 0.735 & 0.783 & 0.217 \\
\hline & 6 & 6859 & 7014 & 7130 & 6948 & 249.6 & 0.918 & 0.428 & 0.202 \\
\hline & 12 & 7933 & 8120 & 8583 & 8350 & $390 \cdot 2$ & 0.908 & 0.044 & 0.303 \\
\hline \multirow[t]{3}{*}{ ADFI } & $0-6$ & 74.9 & 91.0 & $105 \cdot 1$ & $75 \cdot 3$ & $25 \cdot 41$ & 0.603 & 0.578 & 0.096 \\
\hline & $6-12$ & $278 \cdot 8$ & 279.9 & 358.9 & 321.6 & 39.91 & 0.333 & 0.006 & 0.331 \\
\hline & $0-12$ & $176 \cdot 8$ & 184.9 & 231.9 & $198 \cdot 5$ & 28.89 & 0.397 & 0.035 & 0.175 \\
\hline \multirow[t]{3}{*}{$A D G$} & $0-6$ & $26 \cdot 5$ & $48 \cdot 1$ & $64 \cdot 6$ & $41 \cdot 7$ & 40.54 & 0.975 & 0.450 & 0.294 \\
\hline & $6-12$ & $179 \cdot 1$ & 184.3 & 242.3 & 233.7 & $35 \cdot 34$ & 0.927 & 0.008 & 0.702 \\
\hline & $0-12$ & $102 \cdot 8$ & $116 \cdot 2$ & 153.4 & $137 \cdot 7$ & $30 \cdot 42$ & 0.941 & 0.036 & 0.356 \\
\hline \multicolumn{10}{|l|}{ Health status } \\
\hline Diarrhoea incidence & $0-12$ & $14 / 16$ & $16 / 16$ & $7 / 16$ & $11 / 16$ & 0.41 & 0.735 & 0.009 & 0.319 \\
\hline
\end{tabular}

$\mathrm{CT}$, control diet; $\mathrm{WB}$, wheat bran diet; $\mathrm{WB}-\mathrm{ZnO}$, wheat bran and $\mathrm{ZnO}$ diet; $\mathrm{WB} \times \mathrm{ZnO}$, effect of $\mathrm{WB}$ and $\mathrm{ZnO}$ inclusion in the diet.

*Trial 1: in vivo experiment. 
Table 3. SCFA concentration ( $\mu \mathrm{mol} / \mathrm{g}$ fresh matter (FM)) in day 12 after weaning, enterococci and Escherichia coli counts (log colony-forming units/g FM) and lactobacilli population (log copies gen $16 \mathrm{~S}$ rDNA/g FM) in the faeces of piglets early after weaning*

(Mean values with their standard errors, $n 8$ )

\begin{tabular}{|c|c|c|c|c|c|c|c|c|}
\hline & \multicolumn{4}{|c|}{ Diets } & \multirow[b]{2}{*}{ SEM } & \multicolumn{3}{|c|}{$P$} \\
\hline & CT & WB & $\mathrm{ZnO}$ & $\mathrm{WB}-\mathrm{ZnO}$ & & WB & $\mathrm{ZnO}$ & $\mathrm{WB} \times \mathrm{ZnO}$ \\
\hline \multicolumn{9}{|l|}{ SCFA } \\
\hline Total & $71 \cdot 6^{\mathrm{b}}$ & $109 \cdot 7^{a}$ & $59 \cdot 5^{\mathrm{b}}$ & $65 \cdot 1^{b}$ & $18 \cdot 41$ & 0.011 & 0.002 & 0.048 \\
\hline Acetic acid & $42 \cdot 2$ & $56 \cdot 9$ & $37 \cdot 8$ & $35 \cdot 7$ & 12.93 & 0.241 & 0.024 & 0.120 \\
\hline Propionic acid & $17 \cdot 8^{\mathrm{b}}$ & $29 \cdot 2^{\mathrm{a}}$ & $14 \cdot 6^{\mathrm{b}}$ & $14 \cdot 8^{\mathrm{b}}$ & $5 \cdot 32$ & 0.014 & 0.001 & 0.018 \\
\hline Butyric acid & $9 \cdot 5^{\mathrm{b}}$ & $18 \cdot 3^{\mathrm{a}}$ & $10 \cdot 2^{b}$ & $9 \cdot 2^{\mathrm{b}}$ & 3.98 & 0.027 & 0.019 & 0.007 \\
\hline Isoacids & $4 \cdot 3$ & $5 \cdot 1$ & 1.9 & $3 \cdot 2$ & 0.91 & 0.001 & 0.001 & 0.494 \\
\hline \multicolumn{9}{|c|}{ Microbial population } \\
\hline \multicolumn{9}{|l|}{ Day 3} \\
\hline Enterococci & $6 \cdot 1$ & 5.9 & 5.4 & $5 \cdot 8$ & 0.71 & 0.721 & 0.299 & 0.405 \\
\hline E. coli & $6 \cdot 6$ & $6 \cdot 2$ & $6 \cdot 1$ & $6 \cdot 5$ & 0.89 & 0.988 & 0.923 & 0.418 \\
\hline Coliforms & $6 \cdot 9$ & $6 \cdot 6$ & $6 \cdot 2$ & $6 \cdot 8$ & 0.95 & 0.720 & 0.573 & 0.434 \\
\hline \multicolumn{9}{|l|}{ Day 6} \\
\hline Enterococci & $5 \cdot 8$ & $5 \cdot 8$ & $6 \cdot 9$ & 5.9 & 0.73 & 0.166 & 0.158 & 0.186 \\
\hline E. coli & $4 \cdot 9^{a, b}$ & $4 \cdot 3^{a, b}$ & $2 \cdot 6^{\mathrm{b}}$ & $5 \cdot 0^{\mathrm{a}}$ & $1 \cdot 11$ & $0 \cdot 154$ & 0.201 & 0.026 \\
\hline Coliforms & 4.9 & 4.4 & $3 \cdot 6$ & $5 \cdot 1$ & 0.97 & 0.356 & 0.523 & 0.068 \\
\hline \multicolumn{9}{|l|}{ Day 9} \\
\hline Enterococci & $6 \cdot 8$ & $6 \cdot 3$ & $6 \cdot 8$ & $5 \cdot 8$ & 0.56 & 0.016 & 0.405 & 0.418 \\
\hline E. coli & $5 \cdot 0^{\mathrm{a}, \mathrm{b}}$ & $3.9^{b}$ & $4 \cdot 2^{a, b}$ & $5 \cdot 3^{\mathrm{a}}$ & 0.87 & 0.986 & 0.515 & 0.024 \\
\hline Coliforms & $5 \cdot 1^{\mathrm{a}, \mathrm{b}}$ & $4 \cdot 1^{\mathrm{b}}$ & $4 \cdot 7^{\mathrm{a}, \mathrm{b}}$ & $5 \cdot 4^{\mathrm{a}}$ & 0.72 & 0.580 & 0.229 & 0.033 \\
\hline \multicolumn{9}{|l|}{ Day 12} \\
\hline Enterococci & $6 \cdot 3$ & 5.9 & $6 \cdot 8$ & $6 \cdot 7$ & 0.65 & 0.357 & 0.064 & 0.589 \\
\hline E. coli & $6 \cdot 6^{\mathrm{a}}$ & $5 \cdot 2^{b}$ & $5 \cdot 6^{\mathrm{a}, \mathrm{b}}$ & $5 \cdot 9^{a, b}$ & 0.72 & 0.148 & 0.700 & 0.034 \\
\hline Coliforms & $6 \cdot 7^{\mathrm{a}}$ & $5 \cdot 4^{b}$ & $5 \cdot 7^{\mathrm{a}, \mathrm{b}}$ & $6 \cdot 1^{a, b}$ & 0.63 & 0.222 & 0.862 & 0.028 \\
\hline Lactobacilli & 11.9 & $11 \cdot 7$ & 11.1 & 11.5 & 0.47 & 0.761 & 0.084 & 0.532 \\
\hline
\end{tabular}

$\mathrm{CT}$, control diet; WB, wheat bran diet; $\mathrm{WB}-\mathrm{ZnO}$, wheat bran and $\mathrm{ZnO}$ diet; $\mathrm{WB} \times \mathrm{ZnO}$, effect of WB and $\mathrm{ZnO}$ inclusion in the diet.

${ }^{a, b}$ Mean values within a row with unlike superscript letters were significantly different $(P<0.05)$.

*Trial 1: in vivo experiment.

(102 bp) and numerous uncultured rumen bacteria (102-104 bp). Analysing the final part of the electropherograms, animals that received the CT and WB diets showed eight and thirteen TRF of 522-582 bp, respectively, whereas only one TRF ( $575 \mathrm{bp}$ ) was found in the $\mathrm{ZnO}$ group, and three TRF (two of $558 \mathrm{bp}$ and one of $565 \mathrm{bp}$ ) were found in the animals that received the $\mathrm{WB}-\mathrm{ZnO}$ combination. This range of TRF is compatible with different Bacillus species (B. cereus, B. thuringiensis and B. megaterium (578-579bp)), different Streptococcus species ( $S$. mitis, $S$. bovis and $S$. salivarius (570-581 bp)), some Lactococcus species ( $L$. lactis and $L$. garvieae (582-583 bp)) and numerous uncultured rumen bacteria.

\section{Trial 2: in vitro adhesion test}

Table 4 presents the detection times of growth for E. coli K88 and for the non-fimbriated $E$. coli. In the present study, an interaction was found between the $E$. coli strain and the fibre source $(P=0 \cdot 0001)$. Significant differences between the fibre substrates were found related to the adhesion of the two E. coli strains. The E. coli K88 adhered more strongly $(P=0.0001)$ to the WB substrate compared with the other fibre substrates and the negative control treatment. Similarly, the non-fimbriated $E$. coli showed a higher attachment $(P=0.0001)$ to the WB substrate compared with soyabean hulls, sugarbeet pulp, oat hulls and the negative control treatment.
Trial 3: in vitro analysis of interaction between wheat bran and zinc oxide

Table 5 presents the results related to trial 3 as detection times of growth for E. coli K88 and the non-fimbriated E. coli. A significant $(P=0 \cdot 0001)$ interaction between the $\mathrm{ZnO}$ and buffered solutions was found related to the growth of the two E. coli strains. The incorporation of $\mathrm{ZnO}$ in the buffered solution inhibited $(P=0.0001)$ the bacterial growth for both $E$. coli strains in comparison with the negative control. Also, the $\mathrm{ZnO}$ supplementation showed antimicrobial effects when supplemented into the $\mathrm{WB}+$ phytase treatment. However, when it was added to the WB or WB + xylanase treatment, $\mathrm{ZnO}$ did not reduce the growth of $E$. coli.

\section{Discussion}

The influence of zinc oxide and wheat bran on the adaptation of piglets after weaning

The present results showed that a dietary supplementation with a high level of $\mathrm{ZnO}(3 \mathrm{~g} / \mathrm{kg})$ increased the feed intake and average daily gain of the animals and reduced the onset of diarrhoea in weanling piglets during the first days after weaning. These results are in accordance with observations from animal performance studies, in which a larger number of animals were used ${ }^{(31,32)}$. Since $\mathrm{ZnO}$ is known to possess antimicrobial properties, it has been usually assumed that it enhances growth by controlling pathogenic bacteria. In the 
Similarity (\%)

35404550556065707580859095100

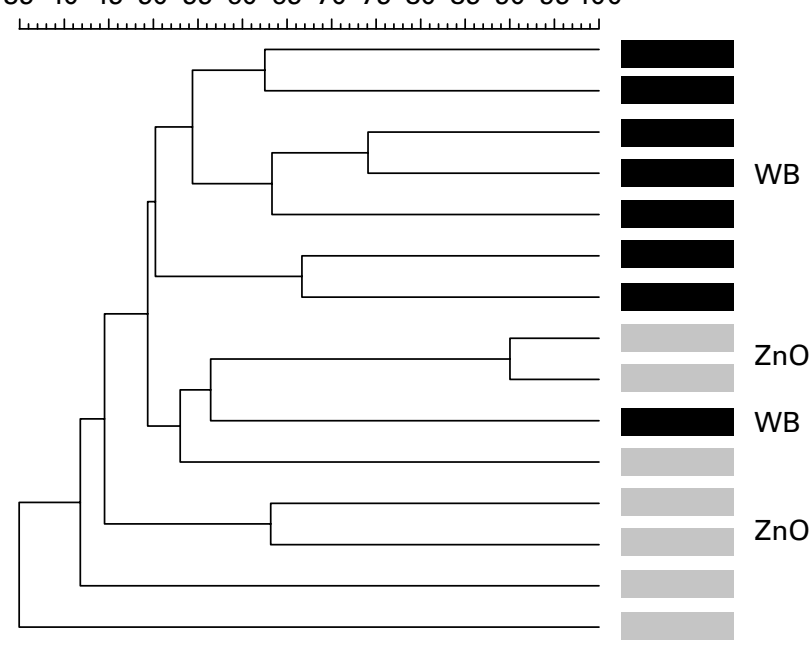

Fig. 1. Dendrogram illustrating the correlation between the experimental diets: $4 \%$ wheat bran (WB) diet and $0.3 \% \mathrm{ZnO}$ diet, in terminal restriction fragment length polymorphism banding patterns of faeces of post-weaning piglets. The dendrogram distances are in percentage of similarity (trial 1: in vivo experiment).

present study, $\mathrm{ZnO}$ reduced the fermentation activity and the counts of lactobacilli and increased the counts of enterococci, as described by Hojberg et al. ${ }^{(24)}$. On the other hand, some studies have also demonstrated that high doses of $\mathrm{ZnO}$ are effective in increasing the feed intake related to modulations of gene expression ${ }^{(9,33)}$. Yin et al. ${ }^{(8)}$ observed that $\mathrm{ZnO}$ supplementation increased plasma levels of ghrelin in early-weaned piglets. Ghrelin is a hormone released by the stomach, which is involved in the secretion of growth hormone and insulin-like growth factor 1 and in the stimulation of the feed intake and muscle growth.

The present results also revealed that $\mathrm{ZnO}$ supplementation decreased the incidence of diarrhoea and the counts of E. coli in faeces, as observed by Cardinal et $a l .^{(7)}$. Diarrhoea in piglets is an important problem, which is associated, in some cases, with an overproliferation of enteropathogenic E. coli. However, animals in the present study presented diarrhoea without a pathological picture of fever, dehydration or apathy. Ou et $a l^{(9)}$ demonstrated that $\mathrm{Zn}$ is also able to ameliorate intestinal inflammation due to inadequate feed intake after weaning by reducing the number of mast cells in the small-intestinal mucosa and submucosa and by inhibiting histamine release from mast cells

In contrast to the results observed with the $\mathrm{ZnO}$ treatments, the incorporation of WB did not improve the productive performance, as was also shown in earlier studies ${ }^{(16,17)}$, but increased the concentration of fermentation products in the faeces, especially the concentration of butyrate. These results confirm that the early-weaned pigs were able to increase carbohydrate fermentation with the inclusion of WB in the diet. It is accepted that starch and bran from wheat or oats stimulate the formation of butyrate ${ }^{(26)}$, which is considered the principal oxidative fuel for colonocytes and may have beneficial trophic effects on the inflamed caeco-colonic mucosa ${ }^{(34)}$. As observed previously with other insoluble fibre sources ${ }^{(17,35)}$, the addition of WB in the diet decreased the E. coli and coliform bacteria counts in faeces. Previous results from our group have also indicated that the incorporation of $\mathrm{WB}$ in the diet also decreased the enterobacteria counts in the caecal digesta ${ }^{(16)}$ and the K88 E. coli attachment to the ileum mucosa after an experimental infection ${ }^{(18)}$. The main mechanism involved in these changes could be an increased fermentation of carbohydrates, which may reduce protein fermentation ${ }^{(14)}$, or likely changes in the physicochemical properties of digesta, which can increase its water-binding capacity or the ability of some long-chain NSP to block the attachment of $E$. coli to the intestinal tract ${ }^{(20)}$

However, a significant two-way interaction was observed between the $\mathrm{WB}$ and $\mathrm{ZnO}$ supplementation. The administration of medicated feed $(\mathrm{ZnO})$ decreased the concentration of SCFA, increased coliform bacteria counts in faeces and reduced some of the microbial groups that were growth promoted when WB was included in the diet. It could be suggested that the antimicrobial effect of $\mathrm{ZnO}$ may have reduced the fermentation of fibre, and the main microbial changes were promoted by the WB supplementation. However, it is also intriguing that the combination of $\mathrm{WB}$ and $\mathrm{ZnO}$ also reduced the effect of therapeutic doses of $\mathrm{ZnO}$ in the counts of $E$. coli and coliform in faeces. The following two trials were designed to test hypotheses evidenced in the in vivo trial: (1) the ability of WB to bind E. coli in the intestinal digesta (trial 2) and (2) the likely mechanisms by which WB may affect the antimicrobial activity of the $\mathrm{ZnO}$ on the E. coli growth in vitro (trial 3).

\section{Potential of different fibrous substrates to bind Escherichia coli}

Different studies have shown the promising effects of glycoconjugates from different origins such as cranberry and

Table 4. Detection times of bacterial growth $t_{\mathrm{OD}}=0.05$ (h) for Escherichia coli $\mathrm{K} 88$, non-fimbriated E. coli, as a measure for adhesion in different fibre ingredients*

(Least-squared means)

\begin{tabular}{|c|c|c|}
\hline Product & $\begin{array}{l}t_{\mathrm{OD}}=0.05 \\
\text { E. coli } \mathrm{K} 88\end{array}$ & $\begin{array}{c}t_{\mathrm{OD}}=0.05 \\
\text { Non-fimbriated } \\
\text { E. coli }\end{array}$ \\
\hline Wheat bran (4\%) & $0.94^{a}$ & $2 \cdot 73^{a}$ \\
\hline Rice hulls (4\%) & $2 \cdot 74^{\mathrm{b}}$ & $2 \cdot 88^{a, b}$ \\
\hline Soyabean hulls (4\%) & $3 \cdot 11^{\mathrm{b}}$ & $3 \cdot 27^{b, c}$ \\
\hline Cereal straw (4\%) & $3 \cdot 12^{b}$ & $3 \cdot 01^{a, b, c}$ \\
\hline Sugarbeet pulp (4\%) & $3 \cdot 22^{\mathrm{b}}$ & $3 \cdot 36^{b, c}$ \\
\hline Pea hulls $(4 \%)$ & $3.00^{\mathrm{b}}$ & $3 \cdot 11^{a, b, c}$ \\
\hline Oat hulls (4\%) & $2 \cdot 69^{\mathrm{b}}$ & $3.43^{\mathrm{c}}$ \\
\hline Negative control & $2 \cdot 92^{b}$ & $3.34^{b, c}$ \\
\hline SEM & 0.193 & \\
\hline \multicolumn{3}{|c|}{$P$} \\
\hline Fibre product & 0.0001 & \\
\hline Bacteria & 0.0001 & \\
\hline Fibre product $\times$ bacteria & 0.0001 & \\
\hline
\end{tabular}

\footnotetext{
a,b,c Mean values within a column with unlike superscript letters were significantly different $(P<0.05)$
}

* Trial 2: in vitro adhesion test. 
Table 5. Detection times of bacterial growth $t_{\mathrm{OD}}=0.05$ (h) for Escherichia coli K88, non-fimbriated E. coli, as a measure of the ability of the $E$. coli strains to grow on different substrates*

(Least-squared means)

\begin{tabular}{|c|c|c|c|}
\hline Items $†$ & $\mathrm{ZnO}$ inclusion & $\begin{array}{l}t_{\mathrm{OD}}=0.05 \\
\text { E. coli } \mathrm{K} 88\end{array}$ & $\begin{array}{c}t_{\mathrm{OD}}=0.05 \\
\text { Non-fimbriated } \\
\text { E. coli }\end{array}$ \\
\hline \multirow[t]{2}{*}{ Negative control } & - & $0.22^{a}$ & $0.24^{a}$ \\
\hline & + & $-{ }^{d} \S$ & $-{ }^{\mathrm{b}} \S$ \\
\hline \multirow[t]{2}{*}{ WB } & - & $0.50^{\mathrm{b}}$ & $0.20^{\mathrm{a}}$ \\
\hline & + & $0.42^{\mathrm{b}}$ & $0.35^{\mathrm{a}}$ \\
\hline \multirow[t]{2}{*}{ WB + phytase } & - & $1 \cdot 10^{\mathrm{C}}$ & $0.45^{\mathrm{a}}$ \\
\hline & + & $1.53^{\mathrm{d}}$ & $-{ }^{\mathrm{b}} \S$ \\
\hline \multirow[t]{2}{*}{ WB + xylanase } & - & $0.33^{a, b}$ & $0 \cdot 17^{\mathrm{a}}$ \\
\hline & + & $0.50^{\mathrm{b}}$ & $0.48^{\mathrm{a}}$ \\
\hline SEM & & 0.502 & \\
\hline \multicolumn{4}{|l|}{$P$} \\
\hline Buffered solutions & & 0.0046 & \\
\hline $\mathrm{ZnO}$ & & 0.0001 & \\
\hline $\begin{array}{l}\text { Buffered } \\
\text { solutions } \times \mathrm{ZnO}\end{array}$ & & 0.0001 & \\
\hline
\end{tabular}

WB, wheat bran.

a,b,c,d Mean values within a column with unlike superscript letters were significantly different $(P<0.05)$.

*Trial 3: in vitro wheat bran and $\mathrm{ZnO}$ test.

† Negative control was based on PBS; the WB inclusion was at a level of $4 \%$, and the phytase and xylanase inclusion was at a level of $0.02 \%(\mathrm{w} / \mathrm{v})$

$\ddagger \mathrm{ZnO}$ inclusion was at a level of $0.3 \%(\mathrm{w} / \mathrm{v})$.

$\S$ Total inhibition of the bacterial growth.

blueberry extracts ${ }^{(36)}$, mannan-oligosaccharides ${ }^{(37,38)}$, palm kernel extracts ${ }^{(39)}$ or soya and fermented soyabean products $^{(40)}$ to inhibit the adhesion of different pathogens such as E. coli or Salmonella to the intestinal mucosa of different animal species. Dietary fibre from plants may provide an alternative adhesion matrix to enteropathogenic bacteria because of their carbohydrate nature similar to the intestinal receptors of such pathogens and low digestibility. Becker \& Galleti $^{(19)}$ tested the binding capacity of different food and feed components for E. coli K88, Salmonella enterica sv. typhimurium and Lactobacillus spp. isolated from pigs, chickens, calves and humans. They reported positive scores for sesame seed extract and soyabean products against $E$. coli K88 in vitro. In recent studies, Kim et al. ${ }^{(35)}$ and Becker et $a l .{ }^{(20)}$ also reported the blocking capacity of oat hulls or pea hulls against $E$. coli K88. In the present study, WB extracts showed the highest ability to bind E. coli K88 among the different fibre sources evaluated. The binding activity was higher in the presence of the F4-fimbriated E. coli K88 in comparison with the non-fimbriated $E$. coli. These results are in good agreement with those we found earlier regarding the reduction promoted by WB on enterobacteria and coliform counts in the digesta and attached E. coli K88 to the ileum mucosa ${ }^{(16,18)}$. WB is one of the more available fibre sources for human and animal feeding. It contains insoluble $\mathrm{NSP}^{(41)}$ mainly as arabinoxylan, cellulose and $\beta$-glucan but also minute levels of glucomannans ${ }^{(42)}$ and arabinogalactans ${ }^{(43)}$ originating from the aleurone and endosperm cells. It might be speculated that the soluble fraction of WB may form a matrix in the gut in which fimbriated $E$. coli is captured. The adhesion of bacteria to the WB matrix may allow their growth, as is observed in the in vitro system, but it also provides a mechanism by which the attachment and proliferation of E. coli K88 at the intestinal epithelium is inhibited or reduced.

\section{Possible mechanism involved in the interaction between wheat bran and zinc oxide}

Negative interactions between $\mathrm{WB}$ and $\mathrm{ZnO}$ have been reported in the present study in vivo and in vitro. In the in vivo trial, the $\mathrm{WB}-\mathrm{ZnO}$ combination did not reduce $E$. coli and the coliform counts as $\mathrm{ZnO}$ or $\mathrm{WB}$ did. In the in vitro trial, the WB-ZnO combination did not have the same antimicrobial effect on the E. coli strains as $\mathrm{ZnO}$ and the combination of WB-phytase and $\mathrm{ZnO}$ did. Therefore, it is suggested that a negative interaction between phytic acid (PA) and $\mathrm{ZnO}$ modifies the antimicrobial properties of therapeutic doses of $\mathrm{ZnO}$ in vivo and in vitro. Champagne \& Fisher ${ }^{(44)}$ suggested that PA, primarily found in the pericarp of cereal grains, may form a rather stable complex with bivalent cations, such as $\mathrm{Cu}^{2+}$ and $\mathrm{Zn}^{2+}$. These complexes are known not to affect $\mathrm{Zn}$ bioavailability in chicks ${ }^{(45)}$ and also in humans ${ }^{(46)}$. Procedures that degrade phytate have been studied as a means to increase the bioavailability of $\mathrm{Zn}$ and other cations in the diet ${ }^{(47,48)}$. It is known that fermentation of feed may reduce the PA: $\mathrm{Zn}$ ratio, promoting a better $\mathrm{Zn}$ absorption ${ }^{(49)}$. Other authors, namely Gaetke et $a l^{(50)}$, also have shown that yogurt (both active and heat-treated) protects against growth retardation in weanling rats fed high PA. In animals, feeding PA has been regarded as an anti-nutrient, which reduces $\mathrm{P}$ availability, and most research in this field has been aimed at eliminating PA from the animal feed by adding exogenous phytase to it. The term phytase is defined as a class of phosphatases with the in vitro capability to release at least one phosphate from $\mathrm{PA}^{(51)}$. Some authors ${ }^{(52,53)}$ have suggested that phytase supplementation may increase the amount of $\mathrm{Zn}$ absorbed, even when pharmacological doses of $\mathrm{Zn}$ are included in the diet. Thus, Martinez et al. ${ }^{(52)}$ suggested that present pharmacological doses of $\mathrm{Zn}$ ( $2000 \mathrm{mg} / \mathrm{kg}$ ) fed to pigs could be reduced to $1000 \mathrm{mg} / \mathrm{kg}$ by adding phytase. The present study confirms a negative interaction between the $\mathrm{WB}$ and therapeutic doses of $\mathrm{ZnO}$, which appears to be related to the high levels of PA in WB. Taking into account these results, phytase supplementation may be proposed as a good approach to increase the effectiveness or to reduce the levels of $\mathrm{ZnO}$ in post-weaning diets.

\section{Conclusion}

Based on the results of the present study, we conclude that the incorporation of WB in the diet of early-weaning piglets may improve their gut health by modulating the activity of the intestinal microbiota, enhancing the fermentation and blocking the attachment of $E$. coli K88 to the intestinal mucosa. A negative interaction observed in vivo and in vitro between WB (rich in phytate) and $\mathrm{ZnO}$ raises the interest of considering the inclusion of phytase enzymes to reduce the required levels of $\mathrm{ZnO}$ in post-weaning diets. 


\section{Acknowledgements}

The present study was supported by the Spanish CICYT (project AGL2005-07438-C02-01). We thank the Ministerio de Educación, Cultura y Deporte, Spain for research fellowships. We also thank the Servei de Granges i Camps Experimentals de la UAB for their service and assistance during the experiment. There are no conflicts of interest between the authors. The contribution of each author to the study has been as follows: F. M., R. G. H., A. G. d. S., S. M. M. and J. F. P. participated in the research and in the writing of the manuscript. J. G. and E. G. M. participated in the writing of the manuscript.

\section{References}

1. Hampson DJ (1994) Escherichia coli in Domestic Animals and Humans, 2nd ed., pp. 171-191 [CL Gyles, editor]. Wallingford, UK: CAB International.

2. Bertschinger HU, Moon HW \& Whipp SC (1972) Association of Escherichia coli with the small intestinal epithelium. I. Comparison of enteropathogenic and nonenteropathogenic porcine strains in pigs. Infect Immun 5, 595-605.

3. Francis DH, Grange PA, Zeman DH, et al. (1998) Expression of mucin-type glycoprotein K88 receptors strongly correlates with piglet susceptibility to K88(+) enterotoxigenic Escherichia coli, but adhesion of this bacterium to brush borders does not. Infect Immun 66, 4050-4055.

4. Verstegen MWA \& Williams BA (2002) Alternatives to the use of antibiotics as growth promoters for monogastric animals. Anim Biotechnol 13, 113-127.

5. Regulation (EC) No 1831/2003 of the European Parliament and the Council. Official Journal of the European Union L 268, 18.10.2003, p. 29.

6. Hayes DJ \& Jenson HH (2003) Briefing Paper 03-BP 41. Lessons from the Danish Ban on Feed-grade Antibiotics. Ames: Iowa State University.

7. Cardinal F, D'Allaire S \& Fairbrother JM (2006) Feed composition in herds with or without postweaning Escherichia coli diarrhea in early-weaned piglets. J Swine Health Prod 14, $10-17$.

8. Yin J, Li X, Li D, et al. (2008) Dietary supplementation with zinc oxide stimulates ghrelin secretion from the stomach of young pigs. J Nutr Biochem 20, 783-790.

9. Ou D, Li D, Cao Y, et al. (2007) Dietary supplementation with zinc oxide decreases expression of the stem cell factor in the small intestine of weanling pigs. J Nutr Biochem 18, 820-826.

10. Nyachoti CM, Omogbenigun FO, Rademacher $\mathrm{M}$, et al. (2006) Performance responses and indicators of gastrointestinal health in early-weaned pigs fed low-protein amino acid-supplemented diets. J Anim Sci 84, 125-134.

11. Heo JM, Kim JC, Hansen CF, et al. (2009) Feeding a diet with decreased protein content reduces indices of protein fermentation and the incidence of postweaning diarrhea in weaned pigs challenged with an enterotoxigenic strain of Escherichia coli. J Anim Sci 87, 2833-2843.

12. Pierce KM, Callan JJ, McCarthy P, et al. (2007) The interaction between lactose level and crude protein concentration on piglet post-weaning performance, nitrogen metabolism, selected faecal microbial populations and faecal volatile fatty acid concentrations. Anim Feed Sci Technol 132, 267-282.

13. Bikker P, Dirkzwager A, Fledderus J, et al. (2006) The effect of dietary protein and fermentable carbohydrates levels on growth performance and intestinal characteristics in newly weaned piglets. J Anim Sci 84, 3337-3345.

14. Hermes RG, Molist F, Ywazaki M, et al. (2009) Effect of dietary level of protein and fiber on the productive performance and health status of piglets. J Anim Sci 87, 3569-3577.

15. Houdijk JGM, Hartemink R, Verstegen MWA, et al. (2002) Effects of dietary non-digestible oligosaccharides on microbial characteristics of ileal chyme and faeces in weaner pigs. Arch Anim Nutr 56, 297-307.

16. Molist F, Gómez de Segura A, Gasa J, et al. (2009) Effects of the insoluble and soluble dietary fibre on the physicochemical properties of digesta and the microbial activity in early weaned piglets. Anim Feed Sci Technol 149, 346-353.

17. Molist F, Ywazaki M, Gómez de Segura A, et al. (2010) Administration of loperamide and addition of wheat bran to the diets of weaner pigs decreases the incidence of diarrhoea and enhance their gut maturation. Br J Nutr 103, 879-885.

18. Molist F, Gómez de Segura A, Perez JF, et al. (2010) Effect of wheat bran on the health and performance of weaned pigs challenged with Escherichia coli ${\mathrm{K} 88^{+}}^{+}$. Livest Sci 133, 214-217.

19. Becker PM \& Galleti S (2008) Food and feed components for gut health-promoting adhesion of E. coli and Salmonella enterica. J Sci Food Agric 88, 2026-2035.

20. Becker PM, van Wikselaar PG, Jansman AJM, et al. (2009) Pea dietary fibre for adhesion and excretion of enterotoxigenic E. coli K88 to prevent intestinal colonization. J Anim Sci $\mathbf{8 7}, 172$.

21. The Council of the European Communities (1986) Council Directive 86/609/EEC of 24 November 1986 on the approximation of laws, regulations and administrative provisions of the Member States regarding the protection of Animals used for Experimental and Scientific purposes. http://europa.eu. int/comm/environment/chemicals/lab_animals/legislation_ en.htm (accessed 25 April 2006).

22. AOAC (1995) Official Methods of Analysis. Arlington, VA: Association of Official Analytical Chemist.

23. Castillo M, Martín-Orúe SM, Manzanilla EG, et al. (2006) Quantification of total bacteria, enterobacteria and lactobacilli populations in pig digesta by real-time PCR. Vet Microbiol 114, 165-170.

24. Hojberg O, Canibe N, Poulsen HD, et al. (2005) Influence of dietary zinc oxide and copper sulfate on the gastrointestinal ecosystem in newly weaned piglets. Appl Environ Microbiol 71, 2267-2277.

25. Castillo M, Martín-Orúe SM, Nofrarías M, et al. (2007) Changes in caecal microbiota and mucosal morphology of weaned pigs. Vet Microbiol 124, 239-247.

26. Jensen BB \& Jorgensen H (1994) Effect of dietary fiber on microbial activity and microbial gas-production in various regions of the gastrointestinal-tract of pigs. Appl Environ Microbiol 60, 1897-1904.

27. Becker PM, Galleti S, Roubos-van den Hil PJ, et al. (2007) Validation of growth as measurand for bacterial adhesion to food and feed ingredients. J Appl Microbiol 103, 2686-2696.

28. Blanco M, Blanco JE, Gonzalez EA, et al. (1997) Genes coding for enterotoxins and verotoxins in porcine Escherichia coli strains belonging to different O:K:H serotypes: relationship with toxic phenotypes. J Clin Microbiol 35, $2958-2963$.

29. SAS Inc (1999) SAS ${ }^{\circledR}$ User's Guide: Statistics. Cary, NC: SAS Inc.

30. Shyu C, Soule T, Bent SJ, et al. (2007) MiCA: a web-based tool for the analysis of microbial communities based on 
terminal-restriction fragment length polymorphisms of $16 \mathrm{~S}$ and $18 \mathrm{~S}$ rRNA genes. Microb Ecol 53, 562-570.

31. Hill GM, Cromwell GL, Crenshaw TD, et al. (2000) Growth promotion effects and plasma changes from feeding high dietary concentrations of zinc and copper to weanling pigs (regional study). J Anim Sci 78, 1010-1016.

32. Case CL \& Carlson MS (2002) Effect of feeding organic and inorganic sources of additional zinc on growth performance and zinc balance in nursery pigs. J Anim Sci 80, 1917-1924.

33. Martinez MM, Hill GM, Link JE, et al. (2002) Effects of pharmacological concentrations of zinc oxide and phytase on zinc excretion and performance in the nursery pig. J Anim Sci 80, 73 .

34. Oufir LE, Barry JL, Flourie B, et al. (2000) Relationships between transit time in man and in vitro fermentation of dietary fiber by fecal bacteria. Eur J Clin Nutr 54, 603-609.

35. Kim JC, Mullan BP, Hampson DJ, et al. (2007) Addition of oat hulls to an extruded rice-based diet for weaner pigs ameliorates the incidence of diarrhoea and reduces indices of protein fermentation in the gastrointestinal tract. $\mathrm{Br} J$ Nutr 99, 1217-1225.

36. Ofek I, Goldhar J \& Sharon N (1996) Anti-Escherichia coli adhesin activity of cranberry and blueberry juices. Adv Exp Med Biol 408, 179-183.

37. Spring P, Wenk C, Dawson KA, et al. (2000) The effects of dietary mannanoligosaccharides on cecal parameters and the concentrations of enteric bacteria in the ceca of salmonella-challenged broiler chicks. Poultry Sci 79, 205-211.

38. Fernandez F, Hinton MH \& Van Gils B (2002) Dietary mannan-oligosaccharides and their effect on chicken caecal microflora in relation to Salmonella enteritidis colonization. Avian Pathol 31, 49-58.

39. Allen VM, Fernandez F \& Hinton MH (1997) Evaluation of the influence of supplementing the diet with mannose or palm kernel meal on Salmonella colonisation in poultry. Br Poultry Sci 38, 485-488.

40. Kiers JL, Nout MJR, Rombouts FM, et al. (2002) Inhibition of adhesion of enterotoxigenic Escherichia coli K88 by soya bean tempe. Lett Appl Microbiol 35, 311-315.

41. Ralet MC, Faulds CB, Williamson G, et al. (1990) Influence of extrusion-cooking on the physicochemical properties of wheat bran. Carbohydrate Res 263, 257-269.
42. Mares DJ \& Stone BA (1973) Studies on wheat endosperm: chemical composition and ultrastructure of cells walls. Aust J Biol Sci 26, 793-812.

43. Fincher GB, Sawyer WH \& Stone BA (1974) Chemical and physical properties of an arabinogalactan peptide from wheat endosperm. Biochem J 139, 535-545.

44. Champagne ET \& Fisher MS (1990) Binding differences of $\mathrm{Zn}(\mathrm{II})$ and $\mathrm{Cu}(\mathrm{II})$ ions with phytate. J Inorg Biochem 38 , 217-223.

45. O'Dell BL \& Savage JE (1960) Effect of phytic acid on zinc availability. Proc Soc Exp Biol Med 103, 304.

46. Hambidge KM, Miller LV, Westcott JE, et al. (2008) Dietary reference intakes for zinc may require adjustment for phytate intake based upon model predictions. I Nutr 138, 2363-2366.

47. Bobilya DJ, Ellersieck MR, Gordon DT, et al. (1991) Bioavailabilities of zinc from nonfat dry milk, lowfat plain yogurt, and soy flour in diets fed to neonatal pigs. J Agric Food Chem 39, 1246-1251.

48. Frontela C, Scarino ML, Ferruzza S, et al. (2009) Effect of dephytinization on bioavailability of iron, calcium and zinc from infant cereals assessed in the Caco-2 cell model. World J Gastroenterol 15, 1977-1984.

49. Hirabayashi M, Matsui T \& Yano H (1998) Fermentation of soybean meal with Aspergillus usamii improves zinc availability in rats. Biol Trace Elem Res 61, 227-234.

50. Gaetke LM, McClain CJ, Toleman CJ, et al. (2009) Yogurt protects against growth retardation in weanling rats fed diets high in phytic acid. $J$ Nutr Biochem 21, 147-152.

51. McCollum EV \& Hart EB (1908) On the occurrence of a phytin-splitting enzyme in animal tissue. J Biol Chem 4 , 497-500.

52. Martinez MM, Hill GM, Link JE, et al. (2004) Pharmacological zinc and phytase supplementation enhance metallothionein mRNA abundance and protein concentration in newly weaned pigs. J Nutr 134, 538-544.

53. Revy PS, Jondreville C, Dourmad JY, et al. (2005) Assessment of dietary zinc requirement of weaned piglets fed diets with or without microbial phytase. J Anim Physiol Anim Nutr 90, $50-59$. 